\title{
A Review of Myeloablative vs Reduced Intensity/Non-Myeloablative Regimens in Allogeneic Hematopoietic Stem Cell Transplantations
}

\author{
Erden Atilla, P1nar Ataca Atilla, Taner Demirer \\ Department of Hematology, Ankara University School of Medicine, Ankara, Turkey
}

Allogeneic hematopoietic stem cell transplantation (Allo-HSCT) is a curative treatment option for both malignant and some benign hematological diseases. During the last decade, many of the newer high-dose regimens in different intensity have been developed specifically for patients with hematologic malignancies and solid tumors. Today there are three main approaches used prior to allogeneic transplantation: Myeloablative (MA), Reduced Intensity Conditioning (RIC) and NonMA (NMA) regimens. MA regimens cause irreversible cytopenia and there is a requirement for stem cell support. Patients who receive NMA regimen have minimal cytopenia and this type of regimen can be given without stem cell support. RIC regimens do not fit the criteria of MA and NMA: the cytopenia is reversible and the stem cell support is necessary. NMA/RIC for AlloHSCT has opened a new era for treating elderly patients and those with comorbidities. The RIC conditioning was used for $40 \%$ of all Allo-HSCT and this trend continue to increase. In this paper, we will review these regimens in the setting of especially allogeneic HSCT and our aim is to describe the history, features and impact of these conditioning regimens on specific diseases.

Keywords: Conditioning regimens, myeloablative, nonmyeloablative, reduced-intensity

\section{INTRODUCTION}

Treatment regimen used for hematopoietic stem cell transplantation (HSCT) must accomplish two goals depending on the patient's disease and the source of stem cells. Since the majority of allogeneic transplantations are performed for the treatment of malignant disease, the regimen must provide tumor cytoreduction and ideally disease eradication (1-8). In the case of allogeneic HSCT the regimen must be sufficiently immunsuppressive to overcome host rejections of the donor stem cells. Most of the high dose chemotherapy regimens defined have been utilized in patients with hematological malignancies in the setting of allogeneic transplantations (9-18).
Several studies showing high doses of total body irridation (TBI) causes death from marrow failure and intravenous infusion of marrow or spleen cells after TBI prevents death in mice attracted many researchers to investigate human transplantations in mid1950s (19). Early trials of human marrow grafting had been unsuccessful since patients failed to engraft or developed fatal graftversus-host disease (GVHD) (20). In late 1960's, investigators had detected that dog leukocyte antigen compatibility between donors and recipients as well as effective drugs to overcome GVHD improved the outcome of Allo-HSCT $(21,22)$. Thomas et al. (23) had reported the results of 100 patients with various hematologic malignancies and aplastic anemia with long-term disease-free survival (DFS) despite high transplant related mortality (TRM)

\footnotetext{
Address for Correspondence: Dr. Taner Demirer, Department of Hematology, Ankara University School of Medicine, Ankara, Turkey

Phone: +905323251065 e-mail: demirer@medicine.ankara.edu.tr

Received: 13 January 2017 Accepted: 19 January 2017•DOI: 10.4274/balkanmedj.2017.0055

Available at www.balkanmedicaljournal.org

Cite this article as:

Attilla E, Ataca Attilla P, Demirer T. A review of myeloablative vs reduced intensity/non-myeloablative regimens in allogeneic hematopoietic stem cell transplantations. Balkan Med J 2017;34:1-9

${ }^{\circ}$ Copyright 2017 by Trakya University Faculty of Medicine / The Balkan Medical Journal published by Galenos Publishing House.
} 
in 1975. Starting from second half of the 1960s up to 1980 s cyclophosphamide and/or TBI as high-dose conditioning regimens were preferred. Busulfan, another alkylating agent, was started to be used as an alternative agent to TBI based regimens and combined with cyclophosphamide in 1983 (24).

Conventional ablative allo-HSCT depends on the tolerated doses of systemic chemo-radiotherapy in order to eradicate malignant tumor burden. This resulted with high regimenrelated toxicities in elderly and patients with comorbidities. In considering that, most hematological diseases occur at ages from 65 to 70 (25), investigators started to seek for less ablative and less toxic conditioning regimens for special populations such as elderly and patients with comorbidities in 1990s. Several studies documented that reduced intensity preparative regimen followed by stem cell infusion was associated with mixed chimerism and then full chimerism with a documented graft vs leukemia (GVL) effect in the setting of hematologic malignancies and graft versus tumor (GVT) effect in the setting of solid tumors (26-32). GVL or GVT effect can be supported by higher risk of relapse in patients who do not develop GVHD, who receives T-cell depleted grafts or those receiving grafts from identical twins and documentation of high remission rates after donor lymphocyte infusions (33). In addition to donor natural killer and B cells, the recognition of host-specific minor or major histocompatibility antigens by donor $\mathrm{T}$ cells may be the mechanisms of GVT effects $(34,35)$.

The MA/NMA/RIC conditioning regimens currently in use summarized in Table 1 (36). Most known RIC regimens include fludarabine and intermediate doses of alkylating agents such as thiotepa, melphalan and busulfan whereas NMA regimens usually contain low-dose (2 Gy) total body irradiation (TBI) with or without fludarabine (37). Such conditioning regimens may cause mild myelosuppression, low treatment-related toxicity and antitumor responses which may continue for extended periods of time. The known complications of AlloHSCT such as pancytopenia, mucositis and organ damage occur less frequently with RIC regimens. It has been suggested that RIC regimens might be associated with an improved survival and lower incidence of relapse than NMA conditioning (38). However Mohty et al. (39) compared the outcomes of NMA $(n=323)$ vs RIC regimens $(n=877)$ in acute myeloid leukemia (AML) and found similar two-year DFS rates between two groups ( $50 \%$ vs $53 \%$, respectively) (39).

It is well known that a complete donor T-cell chimerism is correlated with a low risk of relapse or progression. MA regimens leads to state of full chimerism rather earlier than RIC regimens. Mixed chimerism is detected initially after transplant in most RIC conditioning regimens and in fact graft rejection is more common in RIC Allo-HSCT patients compared to conventional regimens (40). Myeloablative regimens are usually associated with higher incidence of acute GVHD but a similar incidence of chronic GVHD compared to RIC regimens (41). The risk of pancytopenia following RIC conditioning is associated with a lower risk of bacteremia but the risk of fungal infections are rather similar after MA or RIC conditioning (42). The incidences of cytomegalovirus reactivation and disease as well as BK virus-associated hemorrhagic cystitis were not found to be different in MA and RIC regimens (43) but decreased mucosal and early-late organ toxicities occur after RIC regimens (44). Studies in immune reconstitution following allo-HSCT have demonstrated various results since the use of different RIC protocols in different spectrum and some authors have shown a rapid recovery of total lymphocytes, Tregs and memory and naive CD4+ lymphocytes after RIC regimens (45).

\section{Reduced Intensity Conditioning vs Myeloablative Conditioning in Specific Diseases}

\section{Acute Leukemias}

In AML, several retrospective comparisons of RIC and MA conditioning regimens are difficult to evaluate due to different patient populations. Patients who received RIC regimens had more high risk features and comorbidities than those received MA conditioning but the survival rates were found to be similar between RIC and MA conditioning (46). Several comparative studies of RIC vs MA in AML is shown in Table 2. The largest retrospective trial was reported by Center for International Blood and Marrow Transplant Research (CIBMTR) in which higher relapse and inferior survival rates were detected after RIC transplants (47). In a subgroup analysis, the better DFS was shown in patients with favorable characteristics (good performance status, age 40-60, AML in CR1). Bornhauser et al. (48) published a prospective randomized study comparing flu/TBI with Cy/TBI and there were no significant difference in rates of DFS, overall survival (OS), non-relapse mortality (NRM) or relapse. Younger ages of patients and more intense RIC regimen than regular were negative drawbacks of the study. Sebert et al. (49) compared the MA with RIC in patients aged 35 years and over in AML and found that relapse rates and OS were similar. After adjusting for gender, donor/recipient mismatch, cytogenetic risk and CD34+ cells, NRM was significantly lower with the RIC regimen ( $p=0.027)$. Therefore, generally today RIC regimens might be a good choice for patients with AML who have significant comorbidities or older age (50). Increased NRM in elderly patients with comorbidities may worsen the outcome of MA allo-HSCT in acute lymphoblastic leukemia (ALL). Marks et al. (51) had not detected any impact of the conditioning intensity on relapse risk or transplant-related 
mortality (TRM) in Ph negative ALL patients in first or second complete remission (CR) who received allografts from siblings or unrelated donors, (51). Mohty et al. (52) from EMBT group could not demonstrate any effect of conditioning regimen in 127 RIC allo-HSCT and 449 MA related allo-HSCT transplants on leukemia-free survival who were in first or second CR. Hematopoietic Cell Transplantation Society of Japan analyzed 369 MA vs 206 RIC allo-HSCT and there were no statistically significant differences in 3-year OS, DFS and NRM: $51 \%$ vs $53 \%, 47 \%$ vs $39 \%$ and $38 \%$ vs $36 \%$, respectively. RIC regimens were associated with a better OS and DFS in patients who received HLA-mismatched transplantation and were aged $\geq 55$ years (Table 2) (53). Based on these controversial literature data regarding the comparison of RIC vs myeloablative conditioning (MAC) in patients with ALL, one may conclude that further prospective trials and head to head comparisons are needed in order to evaluate efficacy of RIC or MAC regimens in ALL. Recently, the results of phase III multi-center randomized study of Blood and Marrow Transplant Clinical Trials Network (BMT CTN) 0901 have been released. This study compared outcomes on the basis of conditioning intensity in patients with Myelodysplastic syndrome (MDS) and AML. The study concluded that RIC results in higher relapse rates and lower TRM compared to MAC with a statistically significant

TABLE 1. MA/NMA/RIC conditioning regimens currently in use

\begin{tabular}{|c|c|c|c|}
\hline Myeloablative & Total dose (days) & Reduced intensity & Total dose (days) \\
\hline Су/TBI & & Flu/Mel & \\
\hline $\mathrm{Cy}(\mathrm{mg} / \mathrm{kg})$ & $120(-6,-5)$ & Flu $\left(\mathrm{mg} / \mathrm{m}^{2}\right)$ & $150(-7$ to -3$)$ \\
\hline Total body irridation (Gy) & $12-14(-3$ to -1$)$ & $\operatorname{Mel}\left(\mathrm{mg} / \mathrm{m}^{2}\right)$ & $140(-2,-1)$ \\
\hline $\mathrm{Bu} / \mathrm{Cy}$ & & Flu/Bu & \\
\hline $\mathrm{Bu}(\mathrm{mg} / \mathrm{kg})$ & $16(-7$ to -4$)$ & Flu $\left(\mathrm{mg} / \mathrm{m}^{2}\right)$ & $150(-9$ to -5$)$ \\
\hline $\mathrm{Cy}(\mathrm{mg} / \mathrm{kg})$ & $120(-3$ to -2$)$ & $\mathrm{Bu}(\mathrm{mg} / \mathrm{kg})$ & $8-10(-6$ to -4$)$ \\
\hline \multicolumn{4}{|l|}{ BACT } \\
\hline $\mathrm{BCNU}\left(\mathrm{mg} / \mathrm{m}^{2}\right)$ & $200(-6)$ & Flu/Cy & \\
\hline ARA-C $\left(\mathrm{mg} / \mathrm{m}^{2}\right)$ & $800(-5$ to -2$)$ & Flu $\left(\mathrm{mg} / \mathrm{m}^{2}\right)$ & $150(-7$ to -3$)$ \\
\hline $\mathrm{Cy}(\mathrm{mg} / \mathrm{kg})$ & $50(-5$ to -2$)$ & $\mathrm{Cy}(\mathrm{mg} / \mathrm{kg})$ & $140(-2,-1)$ \\
\hline 6-Thioguanine (mg/m²) & $800(-5$ to -2$)$ & & \\
\hline \multicolumn{4}{|l|}{ BEAM } \\
\hline $\mathrm{BCNU}\left(\mathrm{mg} / \mathrm{m}^{2}\right)$ & $300(-6)$ & Flu/Bu/TT & \\
\hline Etoposide $\left(\mathrm{mg} / \mathrm{m}^{2}\right)$ & $800(-5$ to -2$)$ & Flu $\left(\mathrm{mg} / \mathrm{m}^{2}\right)$ & $150(-7$ to -5$)$ \\
\hline ARA-C $\left(\mathrm{mg} / \mathrm{m}^{2}\right)$ & $800(-5$ to -2$)$ & $\mathrm{Bu}(\mathrm{mg} / \mathrm{kg})$ & $8(-6$ to -4$)$ \\
\hline Melphalan $\left(\mathrm{mg} / \mathrm{m}^{2}\right)$ & $140(-1)$ & Thiotepa $\left(\mathrm{mg} / \mathrm{m}^{2}\right)$ & \\
\hline \multicolumn{4}{|l|}{ TBI/VP } \\
\hline Total body irridation (Gy) & $12-13.2(-7$ to -4$)$ & Non-Myeloablative & Total dose (days) \\
\hline Etoposide $(\mathrm{mg} / \mathrm{kg})$ & $60(-3)$ & & \\
\hline AC/TBI & & Flu/TBI & \\
\hline ARA-C $\left(\mathrm{g} / \mathrm{m}^{2}\right)$ & $36(-9$ to -4$)$ & Flu $\left(\mathrm{mg} / \mathrm{m}^{2}\right)$ & $90(-4$ to -2$)$ \\
\hline Total body irridation (Gy) & $12(-3$ to -1$)$ & Total body irridation (Gy) & $2(0)$ \\
\hline Mel/TBI & & TLI/ATG & \\
\hline Melphalan $\left(\mathrm{mg} / \mathrm{m}^{2}\right)$ & $110-140$ & Total lymphoid irridation (Gy) & $8(-11$ to -1$)$ \\
\hline Total body irridation (Gy) & $10-14$ & ATG & $2(0)$ \\
\hline \multicolumn{4}{|l|}{ Cy/VP/TBI } \\
\hline Cy $(\mathrm{mg} / \mathrm{kg})$ & $120(-6,-5)$ & TBI & \\
\hline Etoposide $(\mathrm{mg} / \mathrm{kg})$ & $30-60(-4)$ & Total body irridation (Gy) & $1-2(0)$ \\
\hline Total body irridation (Gy) & $12-13.8(-3$ to -1$)$ & & \\
\hline \multicolumn{4}{|l|}{ TBI/TT/Cy } \\
\hline Total body irridation (Gy) & $13.8(-9$ to -6$)$ & & \\
\hline Thiotepa $(\mathrm{mg} / \mathrm{kg})$ & $10(-5,-4)$ & & \\
\hline $\mathrm{Cy}(\mathrm{mg} / \mathrm{kg})$ & $120(-3,-2)$ & & \\
\hline \multicolumn{4}{|l|}{$\mathrm{Bu} / \mathrm{Cy} / \mathrm{Mel}$} \\
\hline $\mathrm{Bu}(\mathrm{mg} / \mathrm{kg})$ & $16(-7$ to -4$)$ & & \\
\hline Сy $(\mathrm{mg} / \mathrm{kg})$ & $120(-3,-2)$ & & \\
\hline $\operatorname{Mel}\left(\mathrm{mg} / \mathrm{m}^{2}\right)$ & $140(-1)$ & & \\
\hline
\end{tabular}


advantage in RFS for patients receiving MAC. It has to be noted that inclusion of heterogeneous regimens in both RIC and MAC arms and lack of longer follow-up establishes the main weaknesses of the BMT CTN 0901 study (54).

\section{Myelodysplastic Syndrome, Myeloproliferative Neoplasms and Aplastic Anemias}

There are some controversies regarding the impact of conditioning intensity on disease control in MDS. Warlick et

TABLE 2. MA vs RIC regimen in acute leukemias

\begin{tabular}{|c|c|c|c|c|c|c|c|c|c|}
\hline Study & $\begin{array}{l}\text { Patient No/ } \\
\text { Median Age/ } \\
\text { Diagnosis }\end{array}$ & Conditioning & $\begin{array}{c}\text { GVHD } \\
\text { Prophylaxis }\end{array}$ & $\begin{array}{l}\text { Pretransplant } \\
\text { Disease }\end{array}$ & $\begin{array}{l}\text { Acute } \\
\text { GVHD }\end{array}$ & $\begin{array}{l}\text { Chronic } \\
\text { GVHD }\end{array}$ & OS/NRM/DFS & Relapse & Follow-up \\
\hline $\begin{array}{l}\text { Perez- } \\
\text { Simon JA et } \\
\text { al. (47) }\end{array}$ & $\begin{array}{c}\text { MA } \\
(3731) / 42 \\
\text { RIC } \\
(1448) / 51 \\
\text { AML }\end{array}$ & Various \pm ATG & $\mathrm{CSA}+\mathrm{MTX}$ & $\begin{array}{l}\text { CR (MA } 66 \% \\
\text { vs } 52 \% \text { ) }\end{array}$ & $\begin{array}{c}\text { MA } 67 \% \\
\text { vs RIC } \\
44 \% \\
(p=0.001)\end{array}$ & $\begin{array}{c}\text { MA } 63 \% \text { vs } \\
\text { RIC } 71 \% \\
(p=0.084)\end{array}$ & $\begin{array}{c}\text { OS: Not significant } \\
\text { differences at } 3 \\
\text { years }\end{array}$ & $\begin{array}{c}\text { Higher } \\
\text { relapse rate } \\
\text { for } \mathrm{RIC} B M \\
(\mathrm{r}=1.46, \\
\mathrm{p}<0.001) \\
\text { and NMA } \\
(\mathrm{r}=1.73, \\
\mathrm{p}<0.001)\end{array}$ & 406 days \\
\hline $\begin{array}{l}\text { Bornhauser } \\
\text { et al. ( } 48)\end{array}$ & $\begin{array}{c}\text { MA (96)/45 } \\
\text { RIC (99)/44 } \\
\text { AML }\end{array}$ & $\begin{array}{l}\mathrm{CY} / \mathrm{TBI} \text { or } \\
\mathrm{Flu} / \mathrm{TBI} / \mathrm{Cy}\end{array}$ & $\mathrm{CSA}+\mathrm{MTX}$ & $\mathrm{CR}$ & $\begin{array}{c}\text { MA } 24 \% \\
\text { vs RIC } \\
17 \% \\
(\mathrm{p}=0.26)\end{array}$ & $\begin{array}{c}\text { MA } 17 \% \text { vs } \\
\text { RIC } 22 \% \\
(p=0.17)\end{array}$ & $\begin{array}{c}\text { MA vs RIC: } \\
\text { NRM in } 36 \text { months } \\
18 \% \text { vs } 13 \% \\
(\mathrm{p}=0.22), \text { DFS in } \\
36 \text { months } 56 \% \\
\text { vs } 58 \% \text {, OS in } 36 \\
\text { months } 61 \% \text { vs } \\
57 \%\end{array}$ & $\begin{array}{l}\text { MA vs } \\
\text { RIC: The } \\
\text { cumulative } \\
\text { incidence of } \\
\text { relapse at } 36 \\
\text { months in } \\
26 \% \text { vs } 28 \%\end{array}$ & 27 months \\
\hline $\begin{array}{l}\text { McClune, } \\
2010\end{array}$ & $\begin{array}{c}\text { RIC (74) 55/ } \\
\text { MA (452) } \\
46 \\
\text { AML }\end{array}$ & $\begin{array}{c}\mathrm{Flu} / \mathrm{Cy} / \mathrm{TBI} \\
\mathrm{Cy} / \mathrm{TBI} \text { or } \\
\mathrm{Bu} / \mathrm{Cy}\end{array}$ & $\begin{array}{l}\text { CSA+ } \\
\text { tacrolimus/ } \\
\text { MTX }\end{array}$ & $\mathrm{CR}$ & $\begin{array}{c}\text { AML: } \\
33 \%-35 \% \\
\text { MDS: } \\
31 \%-36 \%\end{array}$ & $\begin{array}{c}\text { Age }{ }^{3} 65 \\
\text { years: } \\
45 \%\end{array}$ & $\begin{array}{c}\text { RIC vs MA: OS } 3 \\
\text { year: } 31 \% \text { vs } 54 \% \\
(p=0.02), \text { NRM } 3 \\
\text { year: } 19 \% \text { vs } 25 \% \\
\quad(p=0.55)\end{array}$ & $\begin{array}{l}\text { RIC vs MA: } \\
43 \% \text { vs } 27 \% \\
\quad(p<0.01)\end{array}$ & $\begin{array}{l}\text { 25-37 } \\
\text { months }\end{array}$ \\
\hline $\begin{array}{l}\text { Sebert et al. } \\
(49)\end{array}$ & $\begin{array}{c}\text { RIC (60) 54/ } \\
\text { MA (72) } 44 \\
\text { AML }\end{array}$ & $\begin{array}{c}\text { Flu/Bu, TBI/ } \\
\text { Flu, Flu Mel } \\
\text { Bu/Cy, Cy/ } \\
\text { TBI, Bu/Mel }\end{array}$ & $\begin{array}{c}\mathrm{CSA}+\mathrm{MTX} \\
\mathrm{CSA}+\mathrm{MMF} \\
\mathrm{CSA}+\mathrm{CS}\end{array}$ & $\begin{array}{l}\text { RIC: CR1 72\% } \\
\text { MA: CR1 74\% }\end{array}$ & $\begin{array}{c}\text { RIC 35\% } \\
\text { MAC } \\
\% 61 \\
(p=0.001)\end{array}$ & $\begin{array}{c}\text { RIC 40\% } \\
\text { MAC 28\% } \\
(p=0.32)\end{array}$ & $\begin{array}{c}\text { RIC vs MA } \\
\text { NRM: } 13 \% \text { vs } 28 \% \\
(p=0.009), \text { OS: } 50 \% \\
\text { vs } 43 \%(p=0.38)\end{array}$ & $\begin{array}{c}4 \text { year relapse } \\
\text { rate RIC: } \\
44 \% \\
\text { MAC: } 33 \% \\
(p=0.22)\end{array}$ & 47 months \\
\hline $\begin{array}{l}\text { Marks et al. } \\
(51)\end{array}$ & $\begin{array}{c}\mathrm{RIC}(93) 45 / \\
\mathrm{MA}(1428) \\
28 \\
\text { ALL }\end{array}$ & $\begin{array}{l}\text { Cy/ } \\
\text { TBI } \\
\text { other }\end{array}$ & $\begin{array}{c}\text { TCD (ATG or } \\
\text { alemtuzumab) } \\
\text { Tacrolimus- } \\
\text { CSA } \\
\text { based } \pm \text { MTX } \\
\text { others }\end{array}$ & CR1 52\% & $\begin{array}{l}\text { RIC 39\% } \\
\text { MA 46\% } \\
(p=0.16)\end{array}$ & $\begin{array}{c}\text { RIC } 34 \% \\
\text { MA } 42 \% \\
(p=0.16)\end{array}$ & $\begin{array}{c}\text { MA vs RIC } \\
\text { TRM at } 3 \text { year } \\
33 \% \text { vs RIC } 32 \% \\
(p=0.86), \text { DFS at } 3 \\
\text { year } 41 \% \text { vs } 32 \% \\
(p=0.12) \text { OS at } 3 \\
\text { year } 43 \% \text { vs } 38 \% \\
(p=0.39)\end{array}$ & $\begin{array}{c}\text { Relapse rate } \\
\text { at } 3 \text { year } \\
\text { MAC } 26 \% \\
\text { vs RIC } 35 \% \\
(p=0.08)\end{array}$ & $\begin{array}{l}54 \text { months } \\
\text { MAC, } \\
38 \text { months } \\
\text { RIC }\end{array}$ \\
\hline $\begin{array}{l}\text { Mohty et al. } \\
(52)\end{array}$ & $\begin{array}{c}\text { RIC (127) } \\
\text { 56/ MA } \\
(449) 49 \\
\text { ALL }\end{array}$ & $\begin{array}{l}\mathrm{Flu} / \mathrm{Bu} \\
\mathrm{Flu} / \mathrm{Mel} \\
\mathrm{Cy} / \mathrm{TBI}\end{array}$ & $\begin{array}{c}\text { CSA } \\
\text { CSA+MTX } \\
\text { CSA+MMF }\end{array}$ & $\begin{array}{l}\text { CR1 MA 60\%, } \\
\text { CR1 RIC 55\% }\end{array}$ & $\begin{array}{l}\text { MA 37\% } \\
\text { RIC 29\% }\end{array}$ & $\begin{array}{l}\text { MA } 36 \% \\
\text { RIC 38\% } \\
(p=0.58)\end{array}$ & $\begin{array}{c}\text { MA vs RIC } \\
\text { NRM: } 29 \% \text { vs } 21 \% \\
\text { p }=0.03\end{array}$ & $\begin{array}{c}\text { Relapse } \\
\text { incidence } \\
(31 \% \pm 2 \%) \\
(\mathrm{MAC}) \mathrm{vs} \\
(47 \% \pm 5 \%) \\
(\mathrm{RIC}) \\
(\mathrm{p}<0.001)\end{array}$ & 16 months \\
\hline $\begin{array}{l}\text { Tanaka et } \\
\text { al. (53) }\end{array}$ & $\begin{array}{l}\text { MA (369) } \\
51 / \text { RIC } \\
(206) 58 \\
\text { ALL }\end{array}$ & $\begin{array}{l}\text { Cy combining } \\
\text { regimens, } \\
\text { Flu+TBI }\end{array}$ & $\begin{array}{l}\text { CSA } \\
\text { FK } \\
\text { MTX }\end{array}$ & $\begin{array}{l}\text { CR1 MA } 85 \%, \\
\text { CR1 RIC } 80 \%\end{array}$ & $\begin{array}{l}\text { MA } 41 \% \\
\text { RIC 37\% } \\
(p=0.48)\end{array}$ & $\begin{array}{l}\text { MA } 24 \% \\
\text { RIC } 20 \% \\
(p=0.25)\end{array}$ & $\begin{array}{c}\text { MA vs RIC } \\
\text { OS } 3 \text { year } 51 \% \text { vs } \\
53 \%(p=0.701), \\
\text { DFS } 3 \text { year } 47 \% \text { vs } \\
39 \%(p=0.09), \\
\text { NFM } 3 \text { year, } 38 \% \\
\text { vs } 36 \%(p=0.67)\end{array}$ & $\begin{array}{l}\text { Relapse } \\
\text { incidence } \\
\text { in } 3 \text { year } \\
(\text { MA } 15 \% \text { vs } \\
\text { RIC } 26 \%) \\
(\mathrm{p}=0.008)\end{array}$ & - \\
\hline
\end{tabular}

aGVHD: acute graft versus host disease, Bu: busulfan, BM: bone Marrow, CSA: cyclosporine, cGVHD: chronic graft versus host disease, CR: complete remission, CSP: rorticosteroid, Flu: fludarabin, Mel: melphelan, MTX: methotrexate, MMF: micophenolate mofetil, NRM: non-relapse mortality, OS: overall survival, PFS: progression free survival, RI: relapse incidence, RIC: reduced intensity conditioning, MA: myeloablative, TBI: total body irradiation, AML: acute myeloid leukemia 
al. (55) reported improved disease control with MA regimens. High risk MDS patients $(n=43)$ were treated with MA and T cell depleted alloHSCT resulted in EFS at 1 and 3 years as $47 \%$ and $34 \%$, respectively. The overall toxicity was detected to be similar compared to multiple recorded series using RIC regimens. Martino et al. (56) reported the results of 25 EBMTaffiliated centers including 215 patients. In that study 3-year incidences of relapse, NRM and OS were 45\%, 22\% and 41\%, respectively, associated with the increased risk of TRM with MA regimen. Scott et al. (57) showed, in 150 patients with MDS or AML transformed from MDS, that NMA compared to MA regimen had no impact on three-year OS (27\% vs $48 \%$, $\mathrm{p}=0.56)$, progression free survival (PFS) $(28 \%$ vs $44 \%, \mathrm{p}=0.6)$ and NRM (41\% vs 34\%). Authors reported that there was no correlation between relapse rates and pre-transplant disease control in patients with MDS in contrast to the study showing that patients receiving MA conditioning had lower risk of relapse particularly those in CR (58).

Myeloproliferative neoplasms (MPNs) include a group of clonal and chronic hematologic disorders with similar features. Classical MPNs are chronic myeloid leukemia (CML), idiopathic/primary myelofibrosis (MF), polycythemia vera (PV), essential thrombocytopenia(ET), systemic mastocytosis, chronic neutrophilic leukemia and chronic eosinophilic leukemia (59). Today, patients with CML progressed to accelerated or blast phase or failed to second-generation tyrosine kinase inhibitors (TKIs) or have resistant mutations to TKI may undergo allo-HSCT. An earlier retrospective study by European Group for Blood and Marrow Transplantation (EBMT) Chronic Leukemia Working Party (CLWP) showed a reduction in the TRM with RIC regimens however this did not translate into a significantly improved 3-year survival in patients with EBMT scores of 0 to 2 (60). RIC regimens were usually preferred with cellular immunotherapy and TKIs in which TKIs act concurrently with donor lymphocyte infusion (61). Patients with MF in general are usually older and have comorbidities at the time of of allo-HSCT. In a retrospective cohort comparing MA and RIC regimens in 51 patients with MF observed no significant differences in 3-year OS or PFS (OS 44\% vs 31\%, PFS 44\% vs 24\%, respectively) however the relapse rate was lower $12 \%$ vs $46 \%$ in RIC with a strong trend toward significance $(\mathrm{p}=0.06)(62)$. In a prospective trial conducted by EBMT CLWP, there was no significant difference in NRM in between matched unrelated and HLAmatched sibling RIC transplants, $13 \%$ vs $10 \%$, respectively. The conditioning regimen included busulfan, fludarabine and anti-thymocyte globulin (ATG) and 5-year relapse rate, PFS and OS were $20 \%, 51 \%$ and $67 \%$, respectively (63). On the other hand, a recent study in 53 patients with
MF demonstrated that the cumulative incidence of graft failure within 60 days after allo-HSCT was high (28\%) and associated with the decreasing intensity of the conditioning regimen. Therefore, researchers have recommended to use more intensive conditioning regimens in MF (64). In a large retrospective CIBMTR analysis, 5 year-TRM in 117 patients with advanced PV and ET who received MA $(n=80)$ and RIC/NMA $(n=37)$ conditioning regimens was higher in MA group $(40 \%$ vs $18 \%, p<0.05)$ as well as 1 -year and 5-year relapse rates were lower in patients receiving MA regimens, $8 \%$ vs $33 \%(p=0.003)$ and $9 \%$ vs $41 \%(p<0.05)$, respectively. Last but not least 5-year survival rates were similar in both conditioning regimens (65). In considering the similar OS rates, older ages and comorbidities of these patients with PV and ET, RIC regimens can be more appealing strategy when it comes to allo-HSCT.

In newly diagnosed severe acquired idiopatic aplastic anemia patients younger than 30-40 years, allo-HSCT is the first line treatment of choice (66). The standart conditioning regimen for HLA identical sibling HSCT relies on cyclophophamide combined with or without ATG. However, for older patients the long term survival after HSCT was detected to be lower in both Seattle (67) and European cohorts (68). EBMT Severe Aplastic Anemia Working Party conducted a study comparing reduced intensity, fludarabine-low dose cytarabine and ATG, conditioning regimen versus standart myeloablative regimen in older aplastic anemia patients. The patients who received RIC $(n=30)$ had higher probability of OS than the control group $(n=239)$ when adjusting for recipient's age $(p=0.04)$. The acute and chronic GVHD incidence was detected to be similar in both groups. The authors concluded that RIC regimen might reduce the negative impact of age in older patients (69).

\section{Lymphomas and Chronic Lymphocytic Leukemia}

In patients with Hodgkin's lymphoma (HL), allo-HSCT is generally performed in relapsed disease after autologous HSCT or refractory disease status but MAC followed by allo-HSCT with conventional preparative regimens had been associated with high toxicity rates and TRM in this group of patients. In the era of reduced intensity regimens, EBMT Lymhoma Working Party reported a lower NRM and improved OS with RIC allo-HSCT in patients with relapsed or refractory HL (70). In a retrospective analysis, 285 patients with HL underwent RIC allo-HSCT without any risk factor and had a 3 -year PFS and OS of $42 \%$ and $56 \%$ compared to $8 \%$ and $25 \%$ for patients with one or more risk factors. NRM was detected to be associated with age $>45$, poor performance status, chemo-refractory disease and transplantation before 2002 (71). Sarina et al. (72) in a retrospective evaluation in 185 patients concluded that patients 
with HL relapsing after autologous HSCT have a survival advantage if they undergo RIC allo-HSCT.

Several studies have evaluated the efficacy HSCT following RIC or NMA conditioning as a treatment option in relapse or refractory non-HL (NHL) after failure of autologous HSCT. The PFS rate at 3-year was $82 \%$ in 18 refractory mantle cell lymphoma (MCL) patients treated with NMA conditioning containing fludarabine, cyclophosphamide and rituximab (73). Maris et al. (74) reported an OS and DFS of $65 \%$ and $60 \%$ in 33 relapsed-refractory MCL with 2 Gy of TBI and fludarabine. Whereas, no differences were seen regarding OS and PFS rates between RIC and MA regimens in the EBMT registry in patients with diffuse large B cell NHL relapsing after an autologous HSCT (75).

CLL has an indolent and prolonged clinical course and mostly patients are in older age group. Sorror et al. (76) reported 64 refractory CLL patients with median age of 56 underwent alloHSCT with NMA conditioning. The 2-year estimated OS and DFS rates were $60 \%$ and $52 \%$ with the incidence of acute GVHD of grade II-IV of $61 \%$. In a different study again, Sorror et al. (77) reported that the outcomes of 152 patients with refractory CLL $(n=40)$ or lymphoma $(n=112)$ who received NMA regimen were associated with a 3 -year NRM and OS rates of $25 \%$ and $53 \%$, respectively.

\section{Solid Tumors}

Based on the growing knowledge on the immune system and $\mathrm{T}$ cell biology, allogeneic HSCT also represents a promising approach in some solid tumors. Several EMBT phase I and II studies which were conducted by Solid Tumors Working Party documented the presence of a graft-versus solid tumor effect in patients with various solid tumors such as renal, ovarian, colon and soft tissue sarcomas [27-78]. Aglietta et al. (30) reported the results of RIC allo-HSCT in 39 metastatic colorectal canter patients. Eighty percent of patients were in progressive disease at transplant and acute GVHD occurred in $35 \%$ of patients. Disease was partly controlled in $46 \%$ of patients. In a study reported by Thiel et al. (79) 30 patients with advanced rhabdomyosarcoma underwent allo-HSCT and 3 -year OS was shown to be $20 \%$ associated with a cumulative risk of progression of $67 \%$. Demirer et al. reported that tumor response in solid tumors was associated with the development of acute and chronic GVHD (72). Based on this, Demirer et al. (31) conluded that further improvements would depend on the identification of the antigen targets of GVT and reduction of the toxicity of the procedure. It is very reasonable to state that targeted therapies may improve the immune effect of allogeneic transplantation in a positive way in patient with solid tumors (32).
In conclusion, allogeneic stem cell transplantation is a curative approach in many diseases. The advantages of RIC regimens are lower toxicity profiles and lower NRM rates. RIC or NMA alloHSCT can be a feasible option in geriatric patients and patients with comorbidities. Future studies are needed for a clear-cut understanding of the mechanisms of GVL and GVT effects of donor $\mathrm{T}$ cells and its subsets in order to optimize the efficacy of such treatment modalities as RIC or MAC in allo-HSCT (5).

Conflict of Interest: No conflict of interest was declared by the authors.

\section{REFERENCES}

1. Bacigalupo A, Ballen K, Rizzo D, Giralt S, Lazarus H, Ho V, et al. Defining the intensity of conditioning regimens: working definitions.Biol Blood Marrow Transplant 2009; 15:1628-33.

2. Passweg JR, Baldomero H, Gratwohl A, Bregni M, Cesaro S, Dreger P, et al. The EBMT activity survey:1990-2010. Bone Marrow Transplant 2012;47:906-23.

3. Demirer T, Buckner CD, Appelbaum FR, Besinger WI, Sanders J, Lambert K, et al. Busulfan, cyclophosphamide and fractionated total body irradiation for autologous or syngeneic marrow transplantation for acute and chronic myelogenous leukemia: phase I dose escalation of busulfan based on targeted plasma levels. Bone Marrow Transplant 1996;17:4915 .

4. Demirer T, Buckner CD, Appelbaum FR, Lambert K, Besinger WI, Clift R, et al. Busulfan, cyclophosphamide and fractionated total body irradiation for allogeneic marrow transplantation in advanced acute and chronic myelogenous leukemia: phase I dose escalation of busulfan based on targeted plasma levels. Bone Marrow Transplant 1996;17:3416 .

5. De Giorgi U, Rosti G, Slavin S, Yaniv I, Harousseau JL, Ladenstein R, et al. Salvage high-dose chemotherapy for children with extragonadal germcell tumours. Br J Cancer 2005;93:412-7.

6. Pedrazzoli P, Ledermann JA, Lotz JP, Leyvraz S, Aglietta M, Rosti G, et al. High dose chemotherapy with autologous hematopoietic stem cell support for solid tumors other than breast cancer in adults. Ann Oncol 2006;17:1479-88.

7. Ladenstein R, Pötschger U, Hartman O, Pearson AD, Klingebiel, Castel V, et al. 28 years of high-dose therapy and SCT for neuroblastoma in Europe: lessons from more than 4000 procedures. Bone Marrow Transplant 2008;41(Suppl 2):118-27.

8. Bensinger WI, Demirer T, Buckner CD, Appelbaum FR, Storb R, Lilleby $\mathrm{K}$, et al. Syngeneic marrow transplantation in patients with multiple myeloma. Bone Marrow Transplant 1996;18:527-31.

9. Demirer T, Petersen FB, Bensinger WI, Appelbaum FR, Fafer A, Rowley S, et al. Autologous transplantation with peripheral blood stem cells collected after granulocyte colony-stimulating factor in patients with acute myelogenous leukemia. Bone Marrow Transplant 1996;18:29-34.

10. Demirer T, Celebi H, Arat M, Ustun C, Demirer S, Dilek I, et al. Autoimmune thrombocytopenia in a patient with small cell lung cancer developing after chemotherapy and resolving following autologous peripheral blood stem cell transplantation. Bone Marrow Transplant 1999;24:335-7.

11. Kröger N, Damon L, Zander AR, Wandt H, Derigs G, Ferrante P, et al. Secondary acute leukemia following mitoxantrone-based high-dose chemotherapy for primary breast cancer patients. Bone Marrow Transplant 2003;32:1153-7. 
12. Pedrazzoli P, Ferrante P, Kulekci A, Schiavo R, De Giorgi U, Carminati O, et al. Autologous hematopoietic stem cell transplantation for breast cancer in Europe: critical evaluation of data from the European Group for Blood and Marrow Transplantation (EBMT) Registry 1990-1999. Bone Marrow Transplant 2003;32:489-94.

13. Demirer T, Gooley T, Buckner CD, Petersen FB, Lilleby K, Rowley S, et al. Influence of total nucleated cell dose from marrow harvests on outcome in patients with acute myelogenous leukemia undergoing autologous transplantation. Bone Marrow Transplant 1995;15:907-13.

14. Berry DA, Ueno NT, Johnson MM, Lei X, Caputo J, Smith DA, et al. High-dose chemotherapy with autologous hematopoietic stem-cell transplantation in metastatic breast cancer: overview of six randomized trials . J Clin Oncol 2011;29:3224-31.

15. De Giorgi U, Demirer T, Wandt H, Taverna C, Siegert W, Bornhauser M, et al. Second-line high-dose chemotherapy in patients with mediastinal and retroperitoneal primary non-seminomatous germ cell tumors: the EBMT experience. Ann Oncol 2005;16:146-51.

16. Brunvand MW, Bensinger WI, Soll E, Weaver CH, Rowley SD, Appelbaum FR, et al. High-dose fractionated total-body irradiation, etoposide and cyclophosphamide for treatment of malignant lymphoma: comparison of autologous bone marrow and peripheral blood stem cells. Bone Marrow Transplant 1996;18:131-41.

17. Demirer T, Buckner CD, Appelbaum FR, Clift R, Storb R, Myerson D, et al. High-dose busulfan and cyclophosphamide followed by autologous transplantation in patients with advanced breast cancer. Bone Marrow Transplant 1996;17:769-74.

18. Thomas'Hematopoietic Cell Transplantation Third Edition- Edited By Blume KG, Forman SJ, Appelbaum FR, 2004, Chapter 13 Preparative Regimens and Modification of Regimen-Related Toxicities, Bensinger WI, Spielberger R.

19. Lorenz E, Uphoff D, Reid TR, Shelton E. Modification of irradiation injury in mice and guinea pigs by bone marrow injections. J Natl Cancer Inst 1951;12:197-201

20. Bortin MM. A compendium of reported human bone marrow transplants. Transplantation 1970;9:571-87.

21. Epstein RB, Storb R, Ragde H, Thomas ED. Cytotoxic typing antisera for marrow grafting in littermate dogs. Transplantation 1968;6:45-58.

22. Storb R, Epstein RB, Graham TC, Thomas ED. Methotrexate regimens for control of graft-versus-host disease in dogs with allogeneic marrow grafts. Transplantation 1970;9:240-6.

23. Thomas ED, Storb R, Clift RA, Fefer A, Johnson L, Neiman PE, et al. Bone-marrow transplantation (second of two parts). N Engl J Med 1975;292:895-902.

24. Santos GW, Tutschka PJ, Brookmeyer R, Saral R, Beschorner WE, Bias $\mathrm{WB}$, et al. Marrow transplantation for acute nonlymphocytic leukemia after treatment with busulfan and cyclophosphamide. N Engl J Med 1983;309:1347-53.

25. Molina AJ, Storb RF. Hematopoietic stem cell transplantation in older adults. In: Rowe LM, Lazarus HM, Carella AM, editors. Handbook of bone marrow transplantation. London: Martin Dunitz; 2000:111-37.

26. Baron F, Storb R. Allogeneic hematopoietic cell transplantation as treatment for hematological malignancies: a review. Springer Semin Immunopathol 2004;26:71-94.

27. Peccatori J, Barkholt L, Sormani MP, Bruzzi P, Ciceri F, Zambelli A, et al. Prognostic factors for survival in patients with advanced renal cell carcinoma undergoing nonmyeloablative allogeneic stem cell transplantation. Cancer 2005;104:2099-103.

28. Barkholt L, Bregni M, Remberger M, Blaise D, Peccatori J, Massenkiel $\mathrm{G}$, et al. Allogeneic haematopoietic stem cell transplantation for metastatic renal carcinoma in Europe. Ann Oncol 2006;17:1134-40.

29. Secondino S, Carrabba MG, Pedrazzoli P, Castagna L, Spina F, Grosso F, et al. Reducued intensity stem cell transplantation for advanced soft tissue sarcomas in adults: a retrospective analysis of the European Group for Blood and Marrow Transplantation. Haematologica 2007;92:418-20.
30. Aglietta M, Barkholt L, Schianca FC, Caravelli D, Omazic B, Minotto C, et al. Reduced-intensity allogeneic hematopoietic stem cell transplantation in metastatic colorectal cancer as a novel adoptive cell therapy approach. The European group for blood and marrow transplantation experience. Biology Blood Marrow Transplant 2009;15:326-35.

31. Demirer T, Barkholt L, Blaise D, Pedrazzoli P, Aglietta M, Carella AM, et al. Transplantation of allogeneic hematopoietic stem cells: an emerging treatment modality for solid tumors. Nat Clin Pract Oncol 2008;5:256-67.

32. Pedrazzoli P, Comoli P, Montagna D, Demirer T, Bregni M; EBMT STWP. Is adoptive T-cell therapy for solid tumors coming of age? Bone Marrow Transplant 2012;47:1013-9.

33. Horowitz MM, Gale RP, Sondel PM, Goldman JM, Kersey J, Kolb HJ, et al. Graft-versus-leukemia reactions after bone-marrow transplantation. Blood 1990;75:555-62.

34. Baron F, Petersdorf EW, Gooley T, Sandmaier BM, Malkki M, Chauncey TR, et al. What is the role for donor natural killer cells after nonmyeloablative conditioning? Biol Blood Marrow Transplant 2009;15:580-8.

35. Miklos DB, Kim HT, Miller KH, Guo L, Zorn E, Lee SJ, et al. Antibody responses to $\mathrm{H}-\mathrm{Y}$ minor histocompatibility antigens correlate with chronic graft versus- host disease and disease remission. Blood 2005;105:2973-8.

36. European group for Blood and Marrow Transplantation (EBMT) Handbook 6th edition, Chapter 8. Principals of conditioning. Editors J.Apperley, E. Carreras, E. Gluckman, T. Masszi, 2012.

37. Servais S, Baron F, Beguin Y. Allogeneic hematopoietic stem cell transplantation (HSCT) after reduced intensity conditioning. Transfus Apher Sci 2011;205-10.

38. Baron F, Baker JE, Storb R, Gooley TA, Sandmaier BM, Maris MB, et al. Kinetics of engraftment in patients with hematologic malignancies given allogeneic hematopoietic cell transplantation after nonmyeloablative conditioning. Blood 2004;104:2254-62.

39. Mohty M, Labopin M, Janssen JJWM, Mufti GJ, Cornelissen JJ, Milpied NJ, et al. Comparison of low dose total body irradiation (TBI)-based reduced intensity conditioning (RIC) vs. chemotherapy-based RIC prior to allogeneic stem cell transplantation (allo-SCT) from an HLA identical sibling donor for Acute Myeloid Leukemia (AML) in first complete remission (CR1): a retrospective analysis of 1200 Patients from the Acute Leukemia Working Party of EBMT. Blood 2009;114:1190.

40. Baron F, Maris MB, Sandmaier BM, Storer BE, Sorror M, Diaconescu $\mathrm{R}$, et al. Graft-versus-tumor effects after allogeneic hematopoietic cell transplantation with nonmyeloablative conditioning. J Clin Oncol 2005;23:1993-2003.

41. Mielcarek M, Martin PJ, Leisenring W, Flowers ME, Maloney DG, Sandmaier BM, et al. Graft-versus-host disease after nonmyeloablative versus conventional hematopoietic stem cell transplantation. Blood 2003;102:756-62.

42. Larosa F, Marmier C, Robinet E, Ferrand C, Saas P, Deconinck E, et al. Peripheral T-cell expansion and low infection rate after reduced-intensity conditioning and allogeneic blood stem cell transplantation. Bone Marrow Transplant 2005;35:859-68.

43. Kim SH, Kee SY, Lee DG, Choi SM, Park SH, Kwon JC, et al. Infectious complications following stem cell transplantation: reduced-intensity vs. myeloablative conditioning regimens. Transpl Infect Dis 2013:15:49-59.

44. Aoudjhane M, Labopin M, Gorin NC, Shimoni A, Ruutu T, Kolb HJ, et al. Comparative outcome of reduced intensity and myeloablative conditioning regimen in HLA identical sibling allogeneic haematopoietic stem cell transplantation for patients older than 50 years of age with acute myeloblastic leukaemia: a retrospective survey from the Acute Leukemia Working Party (ALWP) of the European group for Blood and Marrow Transplantation (EBMT). Leukemia 2005;19:2304-12.

45. Jimenez M, Ercilla G, Martinez C. Immune reconstitution after allogeneic stem cell transplantation with reduced-intensity conditioning regimens. Leukemia 2007;21:1628-37. 
46. Luger SM, Ringden O, Zhang MJ, Perez WS, Bishop MR, Bornhauser $\mathrm{M}$, et al. Similar outcomes using myeloablative vs reduced-intensity allogeneic transplant preparative regimens for AML or MDS. Bone Marrow Transplant 2012;47:203-11.

47. Perez-Simon JA, Diez-Campelo M, Martino R, Brunet S, Urbano A, Caballero MD, et al. Influence of the intensity of the conditioning regimen on the characteristics of acute and chronic graft-versus-host disease after allogeneic transplantation. Br J Haematol 2005;130:394-403.

48. Bornhauser M, Kienast J, Trenschel R, Burchert A, Hegenbart U, Stadler $\mathrm{M}$, et al. Reduced-intensity conditioning versus standard conditioning before allogeneic haemopoietic cell transplantation in patients with acute myeloid leukaemia in first complete remission: a prospective, open-label randomised phase 3 trial. Lancet Oncol 2012;13:1035-44.

49. Sebert M, Porcher R, Robin M, Ades L, Boissel N, Raffoux E, et al. Equivalent outcomes using reduced intensity or conventional myeloablative conditioning transplantation for patients aged 35 years and over with AML. Bone Marrow Transplant 2015;50:74-81.

50. Reshef R, Porter DL. Reduced-intensity conditioned allogeneic SCT in adults with AML. Bone Marrow Transplant 2015;759-69.

51. Marks DI, Wang T, Perez WS, Antin JH, Copelan E, Gale RP, et al. The outcome of full-intensity and reduced-intensity conditioning matched sibling or unrelated donor transplantation in adults with Philadelphia chromosome-negative acute lymphoblastic leukemia in first and second complete remission. Blood 2010;116:366-74.

52. Mohty M, Labopin M, Volin L, Gratwohl A, Socie' G, Esteve J, et al. Reduced intensity versus conventional myeloablative conditioning allogeneic stem cell transplantation for patients with acute lymphoblastic leukemia: a retrospective study from the European Group for Blood and Marrow Transplantation. Blood 2010;116:4439-43.

53. Tanaka J, Kanamori H, Nishiwaki S, Ohashi K, Taniguchi S, Eto T, et al. Reduced intensity vs myeloablative conditioning allogeneic hematopoietic SCT for patients aged over 45 years with ALL in remission: a study from the Adult ALL Working Group of the Japan Society for Hematopoietic Cell Transplantation (JSHCT). Bone Marrow Transplant 2013;48:1389-94.

54. Scott B, Pasquini MC, Logan B, Wu J, Devine S, Porter D, et al. Results of a Phase III Randomized, Multi-Center Study of Allogeneic Stem Cell Transplantation after High Versus Reduced Intensity Conditioning in Patients with Myelodysplastic Syndrome (MDS) or Acute Myeloid Leukemia (AML): Blood and Marrow Transplant Clinical Trials Network (BMT CTN) 0901. Late-Breaking Abstracts, 57th ASH Annual Meeting and Exposition, December 2015. http://www.bloodjournal.org/content/126/23/ LBA-8?sso-checked=true

55. Warlick ED, O'Donnell PV, Borowitz M, Grupka N, Decloe L, GarrettMater E, et al. Myeloablative allogeneic bone marrow transplant using $\mathrm{T}$ cell depleted allografts followed by post-transplant GM-CSF in high-risk myelodysplastic syndromes. Leukoc Res 2008;32:1439-47.

56. Martino R, Iacobelli S, Brand R, Jansen T, Van Biezen A, Finke J, et al. Retrospective comparison of reduced-intensity conditioning and conventional high-dose conditioning for allogeneic hematopoietic stem cell transplantation using HLA-identical sibling donors in myelodysplastic syndromes. Blood 2006;108:836-46.

57. Scott BL, Sandmaier BM, Storer B, Maris MB, Sorror ML, Maloney DG, et al. Myeloablative vs nonmyeloablative allogeneic transplantation for patients with myelodysplastic syndrome or acute myelogenous leukemia with multilineage dysplasia: a retrospective analysis. Leukemia 2006;20:128-35.

58. Warlick ED, Cioc A, Defor T, Dolan M, Weisdorf D. Allogeneic stem cell transplantation for adults with myelodysplastic syndromes: importance of pretransplant disease burden. Biol Blood Marrow Transplant 2009;15:308.

59. Adekola K, Popat U, Ciurea SO. An update on allogeneic hematopoietic progenitor cell transplantation for myeloproliferative neoplasms in the era of tyrosine kinase inhibitors. Bone Marrow Transplant 2014;49:1352-9.
60. Crawley C, Szydlo R, Lalancette M, Bacigalupo A, Lange A, Brune M, et al. Outcomes of reduced-intensity transplantation for chronic myeloid leukemia: an analysis of prognostic factors from the Chronic Leukemia Working Party of the EBMT. Blood 2005;106:2969-76.

61. Savani BN, Montero A, Kurlander R, Childs R, Hensel N, Barrett AJ. Imatinib synergizes with donor lymphocyte infusions to achieve rapid molecular remission of CML relapsing after allogeneic stem cell transplantation. Bone Marrow Transplant 2005;36:1009-15.

62. Stewart WA, Pearce R, Kirkland KE, Bloor A, Thomson K, Apperley J, et al. The role of allogeneic SCT in primary myelofibrosis: a British Society for Blood and Marrow Transplantation study. Bone Marrow Transplant 2010;45:1587-93.

63. Kröger N, Holler E, Kobbe G, Bornhauser M, Schwerdtfeger R, Baurmann $\mathrm{H}$, et al. Allogeneic stem cell transplantation after reduced-intensity conditioning in patients with myelofibrosis: a prospective, multicenter study of the Chronic Leukemia Working Party of the European Group for Blood and Marrow Transplantation. Blood 2009;114:5264-70.

64. Slot S, Smits K, Van de Donk NW, Witte BI, Raymakers R, Janssen JJ, et al. Effect of conditioning regimens on graft failure in myelofibrosis: a retrospective analysis. Bone Marrow Transplant 2015;50:1424-31.

65. Ballen KK, Woolfrey AE, Zhu X, Ahn KW, Wirk B, Arora M, et al. Allogeneic hematopoietic cell transplantation for advanced polycythemia vera and essential thrombocythemia. Biol Blood Marrow Transplant 2012;18:1446-54.

66. Marsh JC, Ball SE, Darbyshire P, Gordon-Smith EC, Keidan AJ, Martin A, et al. Guidelines for the diagnosis and management of acquired aplastic anemia. Br J Haematol 2003;123:782-801.

67. Doney K, Leisenring W, Storb R, Appelbaum FR. Primary treatment of acquired aplastic anemia: outcomes with bone marrow transplantation and immunosuppressive therapy. Seattle Bone Marrow Transplant Team. Ann Intern Med 1997;126:107-15.

68. Bacigalupo A, Hows J, Gluckman E, Nissen C, Marsh J, Van Lint MT, et al. Bone marrow transplantation (BMT) versus immunosuppression for the treatment of severe aplastic anemia (SAA): a report of the EBMT SAA working party. Br J Haematol 1988;70:177-82.

69. Maury S, Bacigalupo A, Anderlini P, Aljurf M, Marsh J, Socie G, et al. Improved outcome of patients older than 30 years receiving HLAidentical sibling hematopoietic stem cell transplantation for severe acquired aplastic anemia using fludarabine-based conditioning: a comparision with conventional conditioning regimen. Haematologica 2009;94:1312-15

70. Sureda A, Robinson S, Canals C, Carella AM, Boogaerts MA, Caballero D, et al. Reduced-intensity conditioning compared with conventional allogeneic stem-cell transplantation in relapsed or refractory Hodgkin's lymphoma: an analysis from the Lymphoma Working Party of the European Group for Blood and Marrow Transplantation. J Clin Oncol 2008;26:455-62.

71. Robinson SP, Sureda A, Canals C, Russell N, Caballero D, Bacigalupo A, et al. Reduced intensity conditioning allogeneic stem cell transplantation for Hodgkin's lymphoma: identification of prognostic factors predicting outcome. Haematologica 2009;94:230-8.

72. Sarina B, Castagna L, Farina L, Patriarca F, Benedetti F, Carella AM, et al. Allogeneic transplantation improves overall and progression-free survival of Hodgkin lymphoma patients relapsing after autologous transplantation: a retrospective study based on the time of HLA typing and donor availability. Blood 2010;115:3671-7.

73. Khouri IF, Lee MS, Saliba RM, Jun G, Fayad L, Younes A, et al. Nonablative allogeneic stem-cell transplantation for advanced/recurrent mantle-cell lymphoma. J Clin Oncol 2003;21:4407-12.

74. Maris MB, Sandmaier BM, Storer BE, Chauncey T, Stuart MJ, Maziarz RT, et al. Allogeneic hematopoietic cell transplantation after fludarabine and 2 Gy total body irradiation for relapsed and refractory mantle cell lymphoma. Blood 2004;104:3535-42. 
75. Van Kampen RJ, Canals C, Schouten HC, Nagler A, Thomson KJ, Vernant JP, et al. Allogeneic stem-cell transplantation as salvage therapy for patients with diffuse large B-cell non-Hodgkin's lymphoma relapsing after an autologous stem-cell transplantation: an analysis of the European Group for Blood and Marrow Transplantation Registry. J Clin Oncol 2011;29:1342-8.

76. Sorror ML, Maris MB, Sandmaier BM, Storer BE, Stuart MJ, Hegenbart $\mathrm{U}$, et al. Hematopoietic cell transplantation after nonmyeloablative conditioning for advanced chronic lymphocytic leukemia. J Clin Oncol 2005;23:3819-29.
77. Sorror ML, Storer BE, Maloney DG, Sandmaier BM, Martin PJ, Storb R. Outcomes after allogeneic hematopoietic cell transplantation with nonmyeloablative or myeloablative conditioning regimens for treatment of lymphoma and chronic lymphocytic leukemia. Blood 2008;111:446-52.

78. Gratwohl A, Baldomero H, Demirer T, Rosti G, Dini G, Ladenstein R, et al. Hematopoetic stem cell transplantation for solid tumors in Europe. Ann Oncol 2004;15:653-60.

79. Thiel U, Koscielniak E, Blaeschke F, Grunewald TG, Badoglio M, Diaz MA, et al. Allogeneic stem cell transplantation for patients with advanced rhabdomyosarcoma: a retrospective assessment. Br J Cancer 2013;109:2523-32. 